\title{
Using Facebook for Leveraging Sense of Community in Self-Paced Open and Distance Learning Courses
}

\author{
https://doi.org/10.3991/ijet.v13i05.8192 \\ Serpil Kocdar $\left.{ }^{\square}\right)$, Abdulkadir Karadeniz, Nil Goksel \\ Anadolu University, Eskişehir, Turkey \\ serpilkocdar@gmail.com
}

\begin{abstract}
The purpose of this study was to investigate whether a sense of community could be enhanced via learning activities delivered through a Facebook group within a self-paced distance-learning course. A closed Facebook group was created for a voluntary English as a foreign language course. Four types of learning activities were delivered via the Facebook group including both synchronous and asynchronous structured activities, and synchronous and asynchronous unstructured activities. The study was designed as convergent mixed-method study. Quantitative data were gathered from a total of 179 students by using the Classroom Community Scale; quantitative data were concurrently gathered from 17 students via semi-structured interviews. The results revealed that the sense of community among learners was found to be high, however, the type of learning activities had no effect on building a sense of community. The study was intended to guide teachers, instructors, administrators and practitioners interested in designing and delivering self-paced open and distance learning courses.
\end{abstract}

Keywords-Sense of community, self-paced learning, Facebook, social network sites, open and distance learning

\section{$1 \quad$ Introduction}

Self-paced open and distance learning environments offer increased learner independence and flexibility as they allow learners to study course materials at their own pace $[1 ; 2 ; 3]$. Despite this advantage, such environments generally suffer from a lack of social interaction [1;4]. Perreault, Waldman, Alexander, and Zhao [5] state that one common disadvantage reported by distance-learning students is a lack of face-to-face interaction with other students and instructors, and students may need to talk to the instructor outside of class time. Due to this limited interaction, learners feel isolated which may result in higher high dropouts [4;6]. According to Rovai [7], one strategy that can be used to increase retention among online learners is to provide them with increased affective support by promoting a strong sense of community that can be created through "a combination of facilitation skills, team-building activities, and group interaction" (p.331). Drouin [8] found that the utilization of learning activities, as well as students' perceived interaction with other students and instructors, were correlated with students' perceived sense of community. Similarly, Carman [9] claims 
that, within a self-paced learning environment, the effectiveness of learning increases when meaningful collaborative learning activities are in place. Nevertheless, when compared with cohort-based learning, building collaboration among students can be a challenging task in self-paced courses as students may not be studying the same content at the same time $[1 ; 10]$. However, using social network sites can provide opportunities for interpersonal interaction and facilitate collaborative learning activities [10]. This claim is corroborated by the study of Meishar-Tal, Kurtz, and Pieterse [11], which revealed that the design and operation of a learning activity within a Facebook group created a very intensive and collaborative learning process.

Although the promotion of interaction using learning activities is important when building a sense of community, the precise level of interaction and sense of community students need may differ. A study conducted by Drouin [8] revealed that some students did not desire a sense of community, while other students enjoyed or required social interaction during online learning. Similarly, Rhode [10] explored the dynamics of interaction in a self-paced online learning environment and found that not all forms of interaction were valued equally by learners; furthermore, the study found that effective and informal interactions were as important as formal interactions in determining the quality of online learning experiences. These findings support claims made by Anderson et al. [4] in their study, which assert that "optimizing the flexibility of self-paced learning and the advantages of collaboration and social support remains an open and exciting challenge". Therefore, it is crucial to identify the level of interaction, the type of learning activities concerned, and the sense of community required by students in self-paced distance learning courses as such courses are to be optimally effective.

The purpose of this study is to investigate whether sense of community could be enhanced via learning activities delivered through an informal Facebook group within a self-paced distance learning course. It is hoped that this study will contribute to existing literature, wherein there is a lack of research on self-paced distance learning courses wherein the utilization of social networking sites is explored [12] for leveraging sense of community. The research questions are formulated below:

1. What is the preferred device used by students when connecting to the Facebook group?

2. What are students' preferences regarding the type of learning activities delivered in the Facebook group?

3. Does the Facebook group and the type of activities conducted therein have an impact on building a sense of community in a self-paced course?

4. What are students' opinions regarding the impact of the Facebook group and the learning activities on their learning and achievement, which is a component of a sense of community?

\subsection{Self-paced open and distance learning courses}

Open and distance learning courses can either be group-paced or self-paced [13]. In self-paced courses, students' progress through learning materials individually and 
at their own pace $[2 ; 12]$. Self-paced courses are also referred to as 'learner-paced' or 'self-study' courses [1]. According to Naidu [14], self-paced learning is "a mode of learning that enables individuals to study online or with the help of portable technologies in their own time, at their own pace, and form their own place" (p.260). Selfpaced distance learning courses offer considerable flexibility and independence, allowing students to begin their courses at any time and complete them at their own pace $[1 ; 12]$; though some self-paced distance education courses do have specific start and end dates [1]. Self-paced study offers opportunities for instructors and administrators to reach high number of students at a lower cost, while also providing increased independence for students [12].

\subsection{Sense of community}

A sense of community is one of the critical factors for success in student learning $[7 ; 15 ; 16]$. Rovai [7] defines sense of community as having two components: feelings of connectedness among community members, and commonality of learning expectations and goals. According to Rovai, connectedness refers to a feeling of belonging and acceptance, as well as the creation of bonding relationships. A classroom community can be regarded as a social community in which students share goals, values and knowledge; it involves the feelings such as friendship, cohesion and satisfaction among students [7]. The second component is "the feeling that knowledge and meaning are actively constructed within the community, that the community enhances the acquisition of knowledge and understanding, and that the learning needs of its members are being satisfied" [7] (p.322). According to Rovai and Jordan [17], students who do not feel a sense of community tend to feel isolated and drop out of online courses more easily. Consequently, it is important that researchers find ways to increase the sense of community among such students to decrease dropouts of online learning courses [16].

\subsection{Facebook as a learning environment}

Facebook is a popular social networking site all over the world [18;19], and existing research suggests that a positive relationship exists between Facebook use and learner satisfaction in higher education. According to Wang, Lin, $\mathrm{Yu}$, and $\mathrm{Wu}$ [20], using Facebook assists students to achieve better grades, increases their levels of engagement, and results in higher student satisfaction within the university learning experience. Similarly, when investigating undergraduate mathematics instruction, Gregory, Gregory, and Eddy [21] found that students who actively participated in Facebook learning groups were more engaged in the course, more satisfied with the course, and performed at a higher level than those who did not actively participate in such groups. In a further study, Kabilan, Ahmad, and Abidin [22] found that the students believed Facebook could be utilized as an online environment to facilitate their learning of English. In another study, Mazer, Murphy, and Simonds [23] found that students who experienced more self-disclosure from instructors on Facebook reported higher levels of motivation and learning. Additionally, Facebook enables peer interac- 
tion-a crucial learning source that provides emotional and psychological supportfacilitating academic satisfaction, skill development and performance enhancement [24]. English and Duncan-Howell [25] used Facebook as a tool to enhance peer support among business education students and detected that students' exchanges were mostly of the affective type and facilitated group cohesiveness through encouragement and support. Chou and Pi [26] found that interaction among peers and learners' satisfaction influenced students' intentions positively regarding continuous use of the course Facebook groups as a learning support.

A study conducted by Karimi, Badariah, Ahmad, and Khodabandelou [27] found that students had positive feelings about Facebook regarding perceived learning, a sense of community and the use of the social media platform as a tool for learning English. Similarly, a study by Duncan and Barczyk [28] found that learners thought that Facebook enhanced their sense of social learning, with older students experiencing a stronger effect. Additionally, students thought that Facebook facilitated their communities of practice in terms of knowledge sharing, collaboration, and learnercentered activities. A parallel study by Kenney, Kumar, and Hart [29] used Facebook as an educational community of practice by online doctoral students to achieve their common goals. The study's analysis of participant interactions in the social network revealed that participants shared knowledge, resources, advice, and insights; participants collaborated and communicated with one another to provide feedback, support one another, and - essentially - learned both within and as a community. These findings support that Facebook can be used as a tool for providing pedagogical and social support to enhance a sense of community, satisfaction and learning for learners in higher education.

\section{Method}

The study was designed as convergent mixed-methods study. Within a convergent design approach the intention is to gather different but complementary data on the topic under investigation to facilitate a better understanding of the research problem; quantitative and qualitative data are gathered simultaneously [30]. This design provides corroboration and validation of the research's results. In this study, both quantitative and qualitative data were needed for a complete understanding as to whether a sense of community could be enhanced via learning activities delivered through an informal Facebook group in a self-paced distance-learning course.

\subsection{Research context}

The study was conducted at a public distance-teaching university in Turkey. An English as a foreign language (EFL) course was chosen for the purposes of this study as it was one of the courses under instruction in which students had low achievement levels. The EFL course was a self-paced distance education course with specific start and end dates, and predetermined exam dates. The main medium for instruction was the course textbook, which included a CD and an online platform incorporating learning exercises. Furthermore, the virtual learning environment included learning materi- 
als such as videos, questions, and online practice tests, among others. Use of these materials was optional. The program also included an optional, five-hour long synchronous course each week, which were recorded and broadcast in the virtual learning environment on completion of the course. In addition to these existing learning environments and materials, an informal Facebook group was created for the purposes of this study.

\section{$2.2 \quad$ The study}

The study was conducted in two stages. In the first stage, on completion of the synchronous course designed for the EFL program, an informal and voluntary Facebook group was set up so that students could come together and meet on common ground. The group was established under the name "Distant Learners" and was designed as a social media group for delivering different activities that are synchronous/asynchronous structured activities and synchronous/asynchronous unstructured activities. These activities are as follows:

- Synchronous structured activities (live problem-solving, lecturing)

- Synchronous unstructured activities (live sessions regarding exams, daily life etc.)

- Asynchronous structured activities (lecturing on pictures, sentence corrections and problem solving etc.)

- Asynchronous unstructured activities (one-to-one discussion on exams, daily life etc.).

These activities were carried out throughout the period of an academic year. After implementing these activities, the second stage involved the utilization of the Class Community Scale to determine the reliability and validity of the findings and to reach a more comprehensive judgment on how the students' level of connectedness influenced their learning perceptions. Semi-structured one-to-one interviews were conducted to determine the degree to which students followed the group, students' level of cognitive and affective connectedness to the group, and students' formation of their perceptions and pleasures regarding the group itself.

\subsection{Participants}

There were 1726 students in the Facebook group who joined the group on a voluntary basis. The Classroom Community Scale was posted online in the Facebook group and 179 students completed it. Similarly, a call for in-depth interviews were posted in the Facebook group and 17 of the group members volunteered for the in-depth interviews.

\subsection{Data Collection Tools}

Qualitative and quantitative data were collected concurrently throughout this study. The Classroom Community Scale_-developed by Rovai [7] and adapted into Turkish 
by Öztürk [31] —was used to collect the quantitative data. The original Englishlanguage scale consists of 20 items. The scale has two factors: connectedness and learning; the Turkish form consists of 13, 5-point Likert-type items ranging from "Strongly Disagree" to "Strongly Agree" and has a reliability coefficient of .85. The connectedness factor includes one negative and five positive items; the perceived learning factor includes five negative and two positive items. The scale was applied online using Google Forms. Consequently, 179 students responded to the scale.

Qualitative data were collected by conducting in-depth interviews with 17 volunteering students. A semi-structured interview form was developed by the researchers and contained questions on how students participated in the Facebook group, students' experiences of the group, their sense of connectedness to the group, whether they thought the group contributed to their learning, their complaints, suggestions, and pleasures regarding the group, as well as several questions on the students' demographic information. Before the interviews were conducted, a voluntary participation form was sent to students informing them of the confidentiality of any information pertaining to their identity, confirming that their information would not be shared with third parties, clarifying that the interviews would be recorded, and confirming that they could withdraw from the study at any time. Students who agreed to participate signed the form and returned it online. Each interview session lasted approximately 15 minutes, and was conducted and recorded by the researchers using a conference system in which the video and audio technologies were simultaneously used.

\subsection{Data Analysis}

After simultaneous collation of both quantitative and qualitative data, researchers analyzed the these data separately before merging them to make inferences from the combined findings.

Quantitative data analysis: Data were obtained using the Classroom Community Scale and organized in Excel for statistical analysis. Descriptive and relational analyses were conducted using SPSS software. Data regarding gender, age, connectedness types, and activity preferences were collected using the Scale which consisted of two factors and 13 items of which:

- The maximum score is 30 and the minimum score is six for the connectedness factor,

- The maximum score is 35 and the minimum score is seven for the learning factor,

- The maximum score is 65 and the minimum score is 13 for the entire scale.

Considering the data set, the lower and upper bounds were:

- 10 as the lower bound, 30 as the upper bound for the connectedness factor,

- 14 as the lower bound, 35 as the upper bound for the learning factor,

- 34 as the lower bound, 65 as the upper bound for the entire scale. 
Table 1. The Gender and Age Distribution of Participants

\begin{tabular}{|c|c|c|c|c|c|c|c|c|c|c|c|c|c|c|c|c|c|}
\hline & \multicolumn{14}{|c|}{ Age Category } & \multicolumn{2}{|c|}{ Total } \\
\hline & & \multicolumn{2}{|c|}{$20-25$} & \multicolumn{2}{|c|}{$26-31$} & \multicolumn{2}{|c|}{$32-37$} & \multicolumn{2}{|c|}{$38-43$} & \multicolumn{2}{|c|}{$44-49$} & \multicolumn{2}{|c|}{$50-55$} & \multicolumn{2}{|c|}{$56-61$} & & \\
\hline & & $f$ & $\%$ & $f$ & $\%$ & $f$ & $\%$ & $f$ & $\%$ & $f$ & $\%$ & $f$ & $\%$ & $f$ & $\%$ & $f$ & $\%$ \\
\hline \multirow{2}{*}{ Gender } & $M$ & 9 & 5,03 & 10 & 5,59 & 13 & 7,26 & 13 & 7,26 & 2 & 1,12 & 2 & 1,12 & 1 & 0,56 & 50 & 27,93 \\
\hline & $F$ & 28 & 15,64 & 26 & 14,53 & 25 & 13,97 & 34 & $\mid 18,99$ & 10 & 5,59 & 5 & 2,79 & 1 & 0,56 & 129 & 72,07 \\
\hline \multicolumn{2}{|l|}{ Total } & 37 & 20,67 & 36 & 20,11 & 38 & 21,23 & 47 & 26,26 & 12 & 6,70 & 7 & 3,91 & 2 & 1,12 & 179 & 100,00 \\
\hline
\end{tabular}

As seen in Table 1, of the 179 participants, 50 were male and 129 were female. Participants' ages ranged from 20 to 69 . The Sturges formula was used to categorize participants' age distribution; participants' age range was divided into seven categories. It displayed a normal distribution within its lower and higher bounds and indicated that the participants consist of adult learners with a wide age range.

Qualitative data analysis: One-to-one interviews were conducted with17 participants; three males and 17 females. Screen and audio recordings were made during the interviews and a transcript of the recordings made by the researchers. Two researchers conducted descriptive analysis separately to analyze the transcriptions of 17 one-toone interviews; the inter-coder reliability was found to be $92 \%$. The researchers discussed any disagreements regarding the codes, resolved them, and reached a final agreement. The results were reported using excerpts from the interviews.

\subsection{Validity and reliability}

The quantitative and qualitative data collated not only complemented each other but also corroborated and validated the findings. Rovai's Sense of Community Scale is arguably the most popular scale for measuring a sense of community, and many researchers have used this scale for such measurements across a variety of learning environments [32]. The scale is widely accepted as a valid and reliable measure. Öztürk [31] adapted the scale into Turkish and found that the Cronbach-Alpha reliability coefficient value to be 0.85 . According to Büyüköztürk [33], values above 0.70 are accepted as reliable. Three experts tested the scale to determine its face validity, and the scale was revised accordingly after the experts expressed their views for online use in Google Forms.

Qualitative data were collected using semi-structured interviews. Open-ended questions prepared for the interviews were examined by three experts and revised according to their comments and reflections. Subsequently, two students were interviewed to test the questions. Additionally, data were coded by two of the researchers and their inter-rater reliability was found to be $92 \%$; this can be regarded as an acceptable value as it was above $70 \%$ [34]. The researchers experienced long periods of interaction with participants, which allowed them to develop trust and good relationships with them and procure or illicit intimate answers which consequently contribut- 
ed to the validity of the study findings. Throughout the study, researchers tried to remain neutral by being non-judgmental and striving to report the findings in a balanced manner.

\section{$3 \quad$ Findings}

Findings are presented according to the research questions.

\section{W.1 What is the students' preferred device used to connect to the Facebook group?}

Students' preferences regarding devices when connecting to the Facebook group are presented according to gender and age distribution in Table 2.

As seen in Table 2, students were found to use desktop and mobile technologies to connect to the Facebook group. However, mobile technologies were preferred over other alternatives. Considering the age variable, it was found out that mobile technologies are most intensively used among the middle age group (26-31,32-37, 38-43) and that adult learners also connect to the group while using their mobile devices.

Table 2. Connection Device Preferences According to Gender and Age

\begin{tabular}{|c|c|c|c|c|c|c|c|c|c|c|c|}
\hline \multirow{3}{*}{ 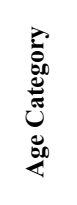 } & \multirow{3}{*}{ 这 } & \multicolumn{6}{|c|}{ Connection Device } & & & & \\
\hline & & \multicolumn{2}{|c|}{$\begin{array}{l}\text { I connect via my } \\
\text { personal comput- } \\
\text { er. }\end{array}$} & \multicolumn{2}{|c|}{$\begin{array}{l}\text { I connect via my } \\
\text { mobile devices such } \\
\text { as phone, tablet. }\end{array}$} & \multicolumn{2}{|c|}{$\begin{array}{c}\text { I connect via my PC } \\
\text { and mobile devices } \\
\text { equally. }\end{array}$} & \multicolumn{4}{|c|}{ Total } \\
\hline & & $f$ & $\%$ & $f$ & $\%$ & $f$ & $\%$ & $f$ & $\%$ & $f$ & $\%$ \\
\hline \multirow{2}{*}{$20-25$} & $M$ & 4 & 2,23 & 4 & 2,23 & 1 & 0,56 & 9 & 5,03 & \multirow{2}{*}{37} & \multirow{2}{*}{20,67} \\
\hline & $\boldsymbol{F}$ & 6 & 3,35 & 15 & 8,38 & 7 & 3,91 & 28 & 15,64 & & \\
\hline \multirow{2}{*}{$26-31$} & $M$ & 3 & 1,68 & 4 & 2,23 & 3 & 1,68 & 10 & 5,59 & \multirow{2}{*}{36} & \multirow{2}{*}{20,11} \\
\hline & $F$ & 3 & 1,68 & 21 & 11,73 & 2 & 1,12 & 26 & 14,53 & & \\
\hline \multirow{2}{*}{$32-37$} & $M$ & 5 & 2,79 & 4 & 2,23 & 4 & 2,23 & 13 & 7,26 & \multirow{2}{*}{38} & \multirow{2}{*}{21,23} \\
\hline & $F$ & 6 & 3,35 & 17 & 9,50 & 2 & 1,12 & 25 & 13,97 & & \\
\hline \multirow{2}{*}{$38-43$} & $M$ & 2 & 1,12 & 8 & 4,47 & 3 & 1,68 & 13 & 7,26 & \multirow{2}{*}{47} & \multirow{2}{*}{26,26} \\
\hline & $F$ & 7 & 3,91 & 26 & 14,53 & 1 & 0,56 & 34 & 18,99 & & \\
\hline \multirow{2}{*}{ 44-49 } & $M$ & - & - & 2 & 1,12 & - & - & 2 & 1,12 & \multirow{2}{*}{12} & \multirow{2}{*}{6,70} \\
\hline & $F$ & 3 & 1,68 & 5 & 2,79 & 2 & 1,12 & 10 & 5,59 & & \\
\hline \multirow{2}{*}{$50-55$} & $M$ & 1 & 0,56 & 1 & 0,56 & - & - & 2 & 1,12 & \multirow{2}{*}{7} & \multirow{2}{*}{3,91} \\
\hline & $F$ & 2 & 1,12 & 3 & 1,68 & - & - & 5 & 2,79 & & \\
\hline \multirow{2}{*}{$56-61$} & $M$ & 1 & - & - & - & - & - & 1 & 0,56 & \multirow{2}{*}{2} & \multirow{2}{*}{1,12} \\
\hline & $\boldsymbol{F}$ & 1 & 0,56 & - & - & - & - & 1 & 0,56 & & \\
\hline \multirow{2}{*}{ Total } & $M$ & 16 & 8,94 & 23 & 12,85 & 11 & 6,15 & 50 & 27,93 & \multirow{2}{*}{179} & \multirow{2}{*}{100,00} \\
\hline & $F$ & 28 & 15,64 & 87 & 48,60 & 14 & 7,82 & 129 & 72,07 & & \\
\hline \multicolumn{2}{|c|}{ Total } & 44 & 24,58 & 110 & 61,45 & 25 & 13,97 & 179 & 100,00 & & \\
\hline
\end{tabular}


3.2 What are students' preferences regarding the type of learning activities delivered in the Facebook group?

Table 3. Students' Preferences of Learning Activities According to Age and Gender

\begin{tabular}{|c|c|c|c|c|c|c|c|c|c|c|c|c|c|}
\hline \multirow{3}{*}{ 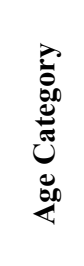 } & \multirow{3}{*}{ نัّ } & \multicolumn{8}{|c|}{ Etkinlik Tercihi } & \multirow{2}{*}{\multicolumn{4}{|c|}{ Total }} \\
\hline & & \multicolumn{2}{|c|}{$\begin{array}{c}\text { Synchro- } \\
\text { nous struc- } \\
\text { tured activi- } \\
\text { ties }\end{array}$} & \multicolumn{2}{|c|}{$\begin{array}{l}\text { Synchro- } \\
\text { nous un- } \\
\text { structured } \\
\text { ativities }\end{array}$} & \multicolumn{2}{|c|}{$\begin{array}{l}\text { Aysnchro- } \\
\text { nous struc- } \\
\text { tured activi- } \\
\text { ties }\end{array}$} & \multicolumn{2}{|c|}{$\begin{array}{l}\text { Asynchro- } \\
\text { nous unstruc- } \\
\text { tured activi- } \\
\text { ties }\end{array}$} & & & & \\
\hline & & $f$ & $\%$ & $f$ & $\%$ & $f$ & $\%$ & $f$ & $\%$ & $f$ & $\%$ & $f$ & $\%$ \\
\hline \multirow{2}{*}{$20-25$} & $M$ & 6 & 3,35 & 1 & 0,56 & 2 & 1,12 & - & - & 9 & 5,03 & \multirow{2}{*}{37} & \multirow{2}{*}{20,67} \\
\hline & $F$ & 15 & 8,38 & 3 & 1,68 & 7 & 3,91 & 3 & 1,68 & 28 & 15,64 & & \\
\hline \multirow{2}{*}{ 26-31 } & $M$ & 4 & 2,23 & - & - & 3 & 1,68 & 3 & 1,68 & 10 & 5,59 & \multirow{2}{*}{36} & \multirow{2}{*}{20,11} \\
\hline & $\boldsymbol{F}$ & 12 & 6,70 & 4 & 2,23 & 6 & 3,35 & 4 & 2,23 & 26 & 14,53 & & \\
\hline \multirow{2}{*}{ 32-37 } & $M$ & 5 & 2,79 & - & - & 7 & 3,91 & 1 & 0,56 & 13 & 7,26 & \multirow{2}{*}{38} & \multirow{2}{*}{21,23} \\
\hline & $F$ & 15 & 8,38 & 1 & 0,56 & 8 & 4,47 & 1 & 0,56 & 25 & 13,97 & & \\
\hline \multirow{2}{*}{$38-43$} & $M$ & 7 & 3,91 & 1 & 0,56 & 4 & 2,23 & 1 & 0,56 & 13 & 7,26 & \multirow{2}{*}{47} & \multirow{2}{*}{26,26} \\
\hline & $F$ & 21 & 11,73 & - & - & 10 & 5,59 & 3 & 1,68 & 34 & 18,99 & & \\
\hline \multirow{2}{*}{ 44-49 } & $M$ & 1 & 0,56 & - & - & 1 & 0,56 & - & - & 2 & 1,12 & \multirow{2}{*}{12} & \multirow{2}{*}{6,70} \\
\hline & $F$ & 7 & 3,91 & - & - & 2 & 1,12 & 1 & 0,56 & 10 & 5,59 & & \\
\hline \multirow{2}{*}{$50-55$} & $M$ & 2 & 1,12 & - & - & - & - & - & - & 2 & 1,12 & \multirow{2}{*}{7} & \multirow{2}{*}{3,91} \\
\hline & $F$ & 1 & 0,56 & 3 & 1,68 & 1 & 0,56 & - & - & 5 & 2,79 & & \\
\hline \multirow{2}{*}{ 56-61 } & $M$ & - & - & - & - & 1 & 0,56 & - & - & 1 & 0,56 & \multirow{2}{*}{2} & \multirow{2}{*}{1,12} \\
\hline & $F$ & 1 & 0,56 & - & - & - & - & - & - & 1 & 0,56 & & \\
\hline \multirow{2}{*}{ Total } & $M$ & 25 & 13,97 & 2 & 1,12 & 18 & 10,06 & 5 & 2,79 & 50 & 27,93 & \multirow{2}{*}{$\begin{array}{c}17 \\
9\end{array}$} & \multirow{2}{*}{100,00} \\
\hline & $\boldsymbol{F}$ & 72 & 40,22 & 11 & 6,15 & 34 & 18,99 & 12 & 6,70 & 129 & 72,07 & & \\
\hline To & & 97 & 54,19 & 13 & 7,26 & 52 & 29,05 & 17 & 9,50 & 179 & 100,00 & & \\
\hline
\end{tabular}

As seen in Table 3, a vast majority of the participants preferred synchronous structured activities. Asynchronous structured activities followed synchronous activities and some participants went online and accessed the group to deal with daily issues. Participants preferred mobiles when connecting to the Facebook group and accessed live video instructions above that of any other activity. These results might stem from the fact that students are able to reach these activities more easily and benefit more from synchronous activities while using a mobile device.

\subsection{Does the Facebook group and the type of activities conducted therein have an impact on building a sense of community in a self-paced course?}

The Classroom Community Scale consists of connectedness and learning factors, and was used to determine a sense of community among the Facebook group. Data 
were collated on 179 students using the Scale; further data were collated using indepth interviews conducted with 17 participants. To eliminate disorder among the frequency distributions, the formula for total scores was used and seven categories were created. The distribution of total scores is presented categorically in Table 4.

Table 4. The Distribution of the Participants' Scores on the Scale

\begin{tabular}{|c|c|c|c|c|}
\hline Total Scores & $\mathbf{f}$ & $\mathbf{\%}$ & cumulative f & cumulative \% \\
\hline $63-67$ & 11 & 6,15 & 11 & 6,15 \\
\hline $58-62$ & 28 & 15,64 & 39 & 21,79 \\
\hline $53-57$ & 33 & 18,44 & 72 & 40,22 \\
\hline $48-52$ & 58 & 32,40 & 130 & 72,63 \\
\hline $43-47$ & 24 & 13,41 & 154 & 86,03 \\
\hline $38-42$ & 17 & 9,50 & 171 & 95,53 \\
\hline $33-37$ & 8 & 4,47 & 179 & 100,00 \\
\hline Total & $\mathbf{1 7 9}$ & $\mathbf{1 0 0 , 0 0}$ & $\mathbf{1 7 9}$ & $\mathbf{1 0 0 , 0 0}$ \\
\hline
\end{tabular}

As seen in Table 4, 86\% of participants scored 43 or higher on the scale; the maximum score of all the participants was 65 . This result indicates that participants' sense of community was of a high level. Only $4 \%$ of the participants expressed opinions that were below the average score obtainable from the scale. The data presented in Table 4 reveals that the participants' sense of community was, generally, of a reasonably high level. The synchronous/asynchronous structured activities and synchronous/asynchronous unstructured activities delivered by individuals in the group had a significant impact on the formation of participants' sense of community. However, in order to determine the individual effect of these activities, further investigation of the relationships among them is needed.

The effect of the activities delivered in the group on students' test scores was investigated using a simple linear regression analysis. However, the analysis failed to report a significant effect $\left(\mathrm{F}(1,177)=4.076, \mathrm{R}^{2}=.017\right)$. Therefore, it can be stated that students' different activity preferences of did not have a direct effect on students' scores on the scale and that the structure of the group and the activity type were both significant regarding the formation of a sense of community.

Within the scope of the study, in-depth interviews were conducted to determine the students' perceptions regarding their sense of community. The analyses of these interviews revealed the following results under the theme of classroom community:

- Noticing people with the same aim and problem; the connectedness of being together, the elimination of loneliness, and the desire to share something more actively within the group due to a sense of community $(\operatorname{Lrn} 2: \ldots$ though I finished 
my course... being able to follow the group... I think to strive to share something in the group),

- Helping other learners, being able to meet new friends, and communicate with them (Lrn 9: ... we are making new friends, follow each other),

- Receiving immediate help from other participants (Lrn 4: I can obtain information from the pictures posted in the Facebook group about the courses I did not attend),

- The elimination of ambiguity in learning through group dynamics, being able to obtain knowledge more easily and make friends in society, and noticing the gains and deficiencies in the learning (Lrn 5: ... with friends... having an exchange of ideas),

- Closing the gap stemming from missing courses with help from other group members, turning virtual friendships into real ones, providing socialization by direct messaging (Lrn 7: It is quite good to be in contact with the group),

- Feeling valued thanks to the group and contributing to the achievement of both oneself and others (Lrn 14: I feel very good, values, it is very good to be able to achieve something and to contribute others' achievement),

- Breaking asociality in regard to the group, learning in a delighted and entertaining way thanks to the group, and providing knowledge about other members' study systems (Lrn 17: ... our friends' posts some information about their study systems in the group).

3.4 What are students' opinions regarding the impact of the Facebook group and the learning activities on their learning and achievement, which is a component of a sense of community?

Table 5. The Distribution of the Participants' Scores Regarding the Learning Factor

\begin{tabular}{|c|c|c|c|c|}
\hline Scores for Learning Factor & $\mathbf{f}$ & $\mathbf{\%}$ & cumulative f & cumulative \% \\
\hline $33-36$ & 51 & 28,49 & 51 & 28,49 \\
\hline $29-32$ & 51 & 28,49 & 102 & 56,98 \\
\hline $25-28$ & 52 & 29,05 & 154 & 86,03 \\
\hline $21-24$ & 16 & 8,94 & 170 & 94,97 \\
\hline $17-20$ & 5 & 2,79 & 175 & 97,77 \\
\hline $13-16$ & 4 & 2,23 & 179 & 100,00 \\
\hline Total & $\mathbf{1 7 9}$ & $\mathbf{1 0 0 , 0 0}$ & $\mathbf{1 7 9}$ & $\mathbf{1 0 0 , 0 0}$ \\
\hline
\end{tabular}

As seen in Table 5, 95\% of the participants who stated that the Facebook group had a significant effect on their learning scored 21 or higher on the scale; the maximum score possible from the scale is 35 . Only $2 \%$ of the participants expressed opinions below the average score obtainable from the scale. The synchronous/asynchronous 
structured activities and synchronous/asynchronous unstructured activities delivered within the group were found to have a significant effect on their learning.

Within the scope of the study, in-depth interviews were conducted to determine the effect of the group on participants' learning. The analyses of these interviews revealed the following results under the themes of perceived learning and academic achievement:

- Learning from other students, obtaining knowledge with them, comprehension and internalization by listening to others (Lrn 3: I learn from my friends when they share something that I do not know in the group, Lrn 4: I can obtain information from the pictures posted in the Facebook group about the courses),

- Recall of prior knowledge (Lrn 7: ...I have forgotten all my previous knowledge. It helped me to recall them),

- Receiving ideas from others regarding a question, eliminating ambiguities, and realizing a student-centered learning and active learning (Lrn 12:... individuals become more active to learn...),

- Learning from others' posts (Lrn 6: ... my knowledge was developed...).

These results supported the quantitative results underlining a positive effect regarding the Facebook group on participants' learning.

The following results highlighted the contributions made by the Facebook group regarding academic achievement.

- Improving academic achievement through group posts, contributing the overall success in the subject, positively affecting exam scores (Lrn 2: ...I passed the exam with a higher score than ever before..., Lrn 13: It provided a great contribution to pass the midterms and exams with a high score...),

- Having difficulties in learning English; however, overcoming them thanks to the group environment,

Realizing an effective learning thanks to the group.

\section{Conclusions and discussion}

The purpose of this study was to investigate whether a sense of community could be enhanced via learning activities delivered through an informal Facebook group in a self-paced distance learning course. A closed Facebook group was created for an informal EFL self-paced course; participation in the group was voluntary. Four types of learning activities were delivered via the Facebook group: synchronous structured activities; synchronous unstructured activities; asynchronous structured activities, and asynchronous unstructured activities.

An EFL course was selected because it was one of the courses in which students had the lowest achievement levels. Arslan and Akbarov [35] mentioned on the difficulties of learning and teaching a foreign language in Turkey and categorized problems as motivation-based and methodology based-problems. Similarly, Nielson [36] pointed out that learning a language was difficult, especially for adult learners, argu- 
ing that a sense of community is a critical component for success among online foreign language learners in terms of engagement in learning and fostering secondlanguage acquisition. The four aforementioned types of learning activity were designed for this study to enhance participants' sense of community. As a result, learners' sense of community was found to be high, while learning activities designed in Facebook had a positive impact on students' feeling of connectedness and learning regarding this EFL self-paced course. These findings support the existing literature which mentions the utilization of Facebook as a tool for providing pedagogical and social support to enhance sense of community, satisfaction and learning for students in higher education $[11 ; 20 ; 21 ; 23 ; 25 ; 26 ; 28 ; 29]$. Additionally, the findings in this study support certain other research in the existing literature regarding the positive impact of using Facebook as a tool for facilitating EFL learning, and enhancing a sense of community and perceived learning [22;27].

Most students in the study reported that they passed the course because of the Facebook group and because of learning activities carried out in the group. They added that their connection with the teacher and other students had a positive impact on their learning. According to Mazer et al. [23], teachers can increase mediated immediacy by including various forms of self-disclosure into their educational practice; their study found that students who experienced more instructor self-disclosure on Facebook reported higher levels of motivation and higher levels of learning. In support of these findings, students in this study expressed their feeling of immediacy when witnessing the personal life of their instructor during live broadcasts via Facebook; for example seeing their instructor at their house drinking her coffee in a relaxed mood or sometimes seeing her son or cat enter the room while speaking. In addition to these findings, peer interaction was an important element regarding students' sense of community. Some students expressed that they learnt from one another; receiving prompt feedback from their classmates or their teacher which contributed to their feeling of connectedness. These findings supported the positive contribution of peer support and interaction regarding students' satisfaction $[24 ; 25 ; 26]$.

Meishar-Tal et al. [11] mentioned the advantages of using Facebook as an alternative to Learning Management Systems as it facilitates interaction, collaboration and active learning. Conversely, Madge, Meek, Wellens, and Hooley [37] claim that Facebook is more suitable for social interaction purposes for students compared to more formal learning and teaching activities. Conversely, the current study supports using Facebook within formal learning practice, especially in self-paced learning environments.

Studies in the literature emphasized the usefulness of designing and delivering learning activities among Facebook groups [11]. According to Drouin [8], the use of asynchronous discussion threads and students' perceived interaction with other students and their instructors were correlated with students' perceived sense of community. Additionally, Shackelford and Maxwell [38] found that "interactions that were most predictive of sense of community were introductions, collaborative group projects, sharing personal experiences, entire class discussions, and exchanging resources" (p.228). Conversely, the type of learning activities designed for the current research had no effect on building a sense of community, although utilization of Fa- 
cebook was nevertheless found to have such a positive impact. It seems that creating opportunities for student-teacher interactions and student-student interactions helped to increase a sense of community regardless of the type of learning activity involved. In addition to these measures, it is important to keep in mind that some students may not value all types of interaction and learning activities; hence instructional designers and teachers should try to balance out independence and interaction while designing learning activities for their students.

Self-paced study facilitates flexible and independent learning opportunities for students while idolatrously offering teachers the availability to reach many students at minimal cost [12]. Providing student-teacher interaction may increase costs and workloads for teachers, so it may not be feasible to provide increased student-teacher interactions per these means due to the large number of students involved in selfpaced learning environments. Consequently, it can be concluded that the utilization of Facebook groups or other social network sites may be a good way of increasing a sense of community in self-paced online learning courses by offering limited teacherstudent interactions, as well as providing more opportunities for student-student interactions wherein the group itself can operate in a self-activating way with limited teacher guidance and support.

This study was intended to guide teachers, instructors, administrators and practitioners interested in designing self-paced open and distance learning courses. Future studies in this research field can potentially utilize different social networks sites to enhance a sense of community. Different online networks can be explored in the future, and increasing research on the use of social network sites in self-paced learning is needed. Various types of learning activities can be designed and researched in prospective studies, and the impact of learning activities on building a sense of community among learners and educators can be investigated across different subjects. Additionally, future research could investigate whether lurkers in such Facebook groups feel a sense of community via the designed learning activities.

\section{$5 \quad$ References}

[1] Anderson, T., Annand, D., \& Wark, N. (2005). The search for learning community in learner-paced distance education programming or "Having your cake and eating it, too!" Australian Journal of Educational Technology, 21(2), 222-241.

[2] Buraphadeja, V., \& Kumnuanta, J. (2011). Enhancing the sense of community and learning experience using self-paced instruction and peer tutoring in a computer-laboratory course. Australasian Journal of Educational Technology, 27(8), 1338-1355. https://doi.org/10.14742/ajet.897

[3] Singh, H., \& Reed, C. (2001). A white paper: Achieving success with blended learning. Centra Software. Retrieved July 12, 2005, from http://www.leerbeleving.nl/wbts/ wbt2014/blend-ce.pdf

[4] Anderson, T., Poellhuber, B., \& McKerlich, P. (2010). Self paced learners meet social software: An exploration of learners' attitudes, expectations and experience. Online Journal of Distance Learning Administration, 13(3), 1556-3847. 
Paper-Using Facebook for Leveraging Sense of Community in Self-Paced Open and Distance Learning...

[5] Perreault, H., Waldman, L., Alexander, M., \& Zhao, J. (2002). Overcoming barriers to successful delivery of distance-learning courses. Journal of Education for Business, 77(6), 313-318. https://doi.org/10.1080/08832320209599681

[6] Croxton, R. A. (2014). The role of interactivity in student satisfaction and persistence in online learning. MERLOT Journal of Online Learning and Teaching, 10(2), 314-325.

[7] Rovai, A. P. (2002). Sense of community, perceived cognitive learning, and persistence in asynchronous learning networks. Internet and Higher Education, 5, 319-332. https://doi.org/10.1016/S1096-7516(02)00130-6

[8] Drouin, M. A. (2008). The relationship between students' perceived sense of community and satisfaction, achievement, and retention in an online course. The Quarterly Review of Distance Education, 9(3), 267-284.

[9] Carman, J.M. (2005). Blended learning design: Five key ingredients. Retrieved from http://www.agilantlearning.com/pdf/Blended\%20Learning\%20Design.pdf

[10] Rhode, J. F. (2009). Interaction equivalency in self-paced online learning environments: An exploration of learner preferences. International Review of Research in Open and Distance Learning, 10(1), 1-23. https://doi.org/10.19173/irrodl.v10i1.603

[11] Meishar-Tal, H., Kurtz, G., \& Pieterse, E. (2012). Facebook groups as LMS: A case study. International Review of Research in Open and Distance Learning, 13(4), 33-48. https://doi.org/10.19173/irrodl.v13i4.1294

[12] Thiessen, J. (2016). Web 2.0 and social media connecting learners in self-paced study: Practitioners' perspectives. Canadian Journal of Learning and Technology, 42(2), 1-14.

[13] Dobrovolny, J. (2006). How adults learn from self-paced, technology-based corporate training: New focus for learners, new focus for designers. Distance Education, 27(2), 155170. https://doi.org/10.1080/01587910600789506

[14] Naidu, S. (2008). Enabling time, pace, and place independence. In J. M. Spector, M.D.Merill, J. Merrienboer, \& M.P.Driscoll (eds.), Handbook of research on educational communications and technology (pp.259-268). New York: Lawrence Erlbaum Associates.

[15] Luo, N., Zhang, M., \& Qi, D. (2017). Effects of different interactions on students' sense of community in e-learning environment. Computers \& Education, 115, 153-160. https://doi.org/10.1016/j.compedu.2017.08.006

[16] Shea, P., Swan, K., \& Pickett, A. (2005). Developing learning community in online asynchronous college courses: The role of teaching presence. Journal of Asynchronous Learning Networks, 9(4), 59-82.

[17] Rovai, A.P., \& Jordan, H.M. (2004). Blended learning and sense of community: A comparative analysis with traditional and fully online graduate courses. International Review of Research in Open and Distance Learning, 5(2), 1-13. https://doi.org/10.19173/irrodl. v5i2.192

[18] Çakır, R., \& Tan, S. S. (2017). Development of educational applications on the social network of Facebook and its effects on students' academic achievement. Educational Sciences: Theory \& Practice, 17, 1525-1546. https://doi.org/10.12738/estp.2017.5.0273

[19] Fırat, M., Altınpulluk, H., Kılınç, H., \& Büyük, K. (2017). Determining open education related social media usage trends in Turkey using a holistic social network analysis. Educational Sciences: Theory \& Practice, 17, 1361-1382. https://doi.org/10.12738/estp.2017. 4.0266

[20] Wang, J., Lin, C. C., Yu, W. W., \& Wu, E. (2013). Meaningful engagement in Facebook learning environments: Merging social and academic lives. Turkish Online Journal of Distance Education, 14(1), 302-322. https://doi.org/10.1080/01587919.2013.835779 
[21] Gregory, P., Gregory, K., \& Eddy, E. (2014). The instructional network: Using Facebook to enhance undergraduate mathematics instruction. Journal of Computers in Mathematics and Science Teaching, 33(1), 5-26.

[22] Kabilan, M. K., Ahmad, N., \& Abidin, M. J. Z. (2010). Facebook: An online environment for learning of English in institutions of higher education. The Internet and Higher Education, 13(4), 179-187. https://doi.org/10.1016/j.iheduc.2010.07.003

[23] Mazer, J.P., Murphy, R. E., \& Simonds, C.J. (2007). I'll see you on "Facebook": The effects of computer-mediated teacher self-disclosure on student motivation, affective learning, and classroom climate. Communication Education. 56(1), 15-17. https://doi.org/10.1080/03634520601009710

[24] Yu, A. Y., Tian, S. W., Vogel, D., \& Kwok, R. C. W. (2010). Can learning be virtually boosted? An investigation of online social networking impacts. Computers \& Education, 55(4), 1494-1503. https://doi.org/10.1016/j.compedu.2010.06.015

[25] English, R. M., \& Duncan-Howell, J. A. (2008). Facebook goes to college: Using social networking tools to support students undertaking teaching practicum. Journal of Online Learning and Teaching, 4(4), 596-601.

[26] Chou, C. H., \& Pi, S. M. (2015). The effectiveness of Facebook groups for e-learning. International Journal of Information and Education Technology, 5(7), 477-82. https://doi.org/10.7763/IJIET.2015.V5.553

[27] Karimi, L., Ahmad, T., \& Khodabandelou, R. (2013). Sense of community and English perceived learning in a social networking site: A study of Facebook. International Journal of e-Education, e-Business, e-Management and e-Learning, 3(3), 224-228. https://doi.org/10.7763/IJEEEE.2013.V3.228

[28] Duncan, D. G., \& Barczyk, C. C. (2013). Facebook in the university classroom: Do students perceive that it enhances community of practice and sense of community. International Journal of Business and Social Science, 4(3), 1-14.

[29] Kenney, J., Kumar, S., \& Hart, M. (2013). More than a social network: Facebook as a catalyst for an online educational community of practice. International Journal of Social Media and Interactive Learning Environments,1(4), 355-369. https://doi.org/10.1504/IJSMILE. 2013.057467

[30] Creswell, J. W., \& Plano Clark, V. L. (2017). Designing and conducting mixed methods research. USA: SAGE Publications.

[31] Öztürk, E. (2009). Sınıf topluluğu ölçeğinin Türkçe'ye uyarlanması: Geçerlik ve güvenirlik çalıșması. Hacettepe Üniversitesi Eğitim Fakültesi Dergisi, 36, 193-202.

[32] Randolph, J.J., \& Crawford, L.M. (2013). Factorial validity and reliability of the sense of community in online courses scale. Journal of Interactive Online Learning, 12(2), 53-69.

[33] Büyüköztürk, Ş. (2009). Sosyal bilimler için veri analizi el kitabı. Ankara: Pegem Akademi.

[34] Yıldırım, A., \& Şimşek, H. (2016). Sosyal bilimlerde nitel araştırma yöntemleri. Ankara: Seçkin Yayınları.

[35] Arslan, M., \& Akbarov, A. (2010). Türkiye'de yabancı dil öğretiminde motivasyon-yöntem sorunu ve çözüm önerileri. Selçuk Üniversitesi Edebiyat Fakültesi Dergisi, 24, 179-191.

[36] Nielson, K. B. (2011). Self-study with language learning software in the workplace: What happens? Language Learning \& Technology, 15(3), 110-129.

[37] Madge, M., Meek, J., Wellens, J., \& Hooley, T. (2009). Facebook, social integration and informal learning at university: 'It is more for socialising and talking to friends about work than for actually doing work'. Learning, Media and Technology, 34(2), 141-155. https://doi.org/10.1080/17439880902923606 
Paper-Using Facebook for Leveraging Sense of Community in Self-Paced Open and Distance Learning..

[38] Shackelford, J. L., \& Maxwell, M. (2012). Sense of community in graduate online education: Contribution of learner to learner interaction. International Review of Research in Open and Distance Learning, 13(4), 228-249. https://doi.org/10.19173/irrodl.v13i4.1339

\section{Authors}

Serpil Kocdar is with Anadolu University, Open Education Faculty, Eskişehir, Turkey.

Abdulkadir Karadeniz is with Anadolu University, Open Education Faculty, Eskişehir, Turkey.

Nil Goksel is with Anadolu University, Schol of Foreign Languages, Eskişsehir, Turkey.

Article submitted 03 January 2018. Resubmitted 13 and 27 February 2018. Final acceptance 25 March 2018. Final version published as submitted by the authors 